JPSCR: Journal of Pharmaceutical Science and Clinical Research, 2020, 02, 151-164

DOI: $10.20961 /$ jpscr.v5i2.39763

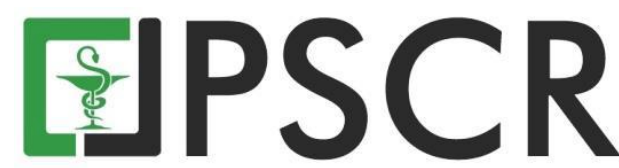

\title{
Profil Pasien dan Penggunaan Antibiotik pada Kasus Community-Acquired Pneumonia Rawat Inap di Rumah Sakit Akademik Wilayah Sukoharjo
}

\author{
Yeni Farida $^{1 *}$, Verina W. Putri ${ }^{1}$, Muchtar Hanafi ${ }^{2}$ dan Nurmayda S. Herdianti ${ }^{2}$ \\ ${ }^{1}$ Program Studi Farmasi, Universitas Sebelas Maret, Jl. Ir. Sutami 36A, Surakarta, Indonesia, 57126 \\ ${ }^{2}$ Rumah Sakit Universitas Sebelas Maret, Jalan Ahmad Yani Nomor 200, Makamhaji, Kartasura, Sukoharjo, \\ Jawa Tengah, Indonesia, 57161 \\ *email korespondensi: yenifarida@staff.uns.ac.id
}

Received 07 Pebruary 2020, Accepted 13 October 2020, Published 30 October 2020

\begin{abstract}
Abstrak: Pneumonia merupakan penyakit infeksi yang masih menjadi permasalahan di dunia turut menyumbang angka mortalitas dan morbiditas. Penyakit infeksi dapat disebabkan oleh bakteri, virus, dan jamur. Pengobatan utama penyakit infeksi akibat bakteri adalah penggunaan antibiotik. Tingginya intensitas penggunaan antibiotik yang dapat menimbulkan berbagai permasalahan dan ancaman bagi kesehatan perlu untuk dikaji. Penelitian ini bertujuan untuk mengetahui karakteristik pasien dan kesesuaian penggunaan antibiotik serta potensi interaksi obat yang dapat terjadi pada peresepan obatnya. Penelitian dilakukan pada subjek pasien dengan diagnosis Community-Acquired Pneumonia (CAP) yang dirawat inap pada periode 2018. Data diambil secara retrospektif dari rekam medis dan dianalisis secara deskriptif untuk mengetahui profil pasien dan penggunaan obatnya. Potensi interaksi obat dianalisis dengan Medscape drug interaction checker kemudian dilanjutkan dengna penelusuran informasi dari Stockley Drug Interaction. Hasil penelitian menunjukkan bahwa sebagian besar pasien pneumonia adalah pasien usia $>65$ tahun $(43,6 \%)$ berjenis kelamin laki-laki $(54,5 \%)$ dengan lama perawatan 1-7 hari (81,8\%), derajat keparahan (CURB-65) terbanyak "Ringan" (45,5\%), dan penyakit komorbid terbanyak adalah kardiovaskuler $(50,9 \%)$. Terapi antibiotik tunggal terbanyak adalah levofloxacin $(38,2 \%)$, evaluasi penggunaan obat yang telah sesuai sebanyak $14,5 \%$, dan potensi interaksi obat terbanyak pada levofloxacin dengan methylprednisolon $(26,4 \%)$. Adanya potensi interaksi obat yang ditemukan diharapkan dapat menjadi perhatian klinisi dalam memberikan terapi.
\end{abstract}

Kata kunci: antibiotik, Community Acquired Pneumonia; interaksi obat; pasien

\begin{abstract}
Patients profile and antibiotiks use in Community Acquired Pneumonia inpatient in Sukoharjo Teaching Hospital. Pneumonia remain as global problem of infectious diseases due to increases of mortality and morbidity rates. The main treatment for infectious diseases due to bacteria is antibiotiks. Study about problems and threats caused by high intensity of antibiotics use was important. An obseravtional study to determine the profile of patients and drug use of pneumonia patients was conducted retrospectively in Community Acquired Pneumonia (CAP) Patients inpatient on 2018 . Dominantly, studied subject were $>65$ years old and male. Most of patients had length of stay for 1-7 days (81.8\%). Cardiovascular disease were the most comorbide (50.9\%). Levofloxacin was dominantly used as monotherapy (38.2\%). While based on culture data and guidelines, $14.5 \%$ of antibiotics used was appropriate. Among drug used, combination of levofloxacin and methylprednisolone was the most potential drug interaction $(26.4 \%)$.
\end{abstract}


Keywords: antibiotics; Community Acquired Pneumonia; drug interactions; patients

\section{Pendahuluan}

Pneumonia merupakan suatu penyakit infeksi yang masih menjadi permasalahan di dunia serta turut menyumbang angka mortalitas dan morbiditas yang berarti. Afrika dan Asia termasuk dalam 10 negara tertinggi kasus infeksi pneumonia (Iliyasu, Mohammad, \& Habib, 2018) . Di Indonesia sendiri, prevalensi kejadian pneumonia naik dari 4,0\% pada tahun 2013 menjadi 4,5\% pada tahun 2018 (Kementerian Kesehatan Republik Indonesia, 2018). Pneumonia disebabkan oleh bakteri, virus, dan jamur. Namun bakteri diketahui sebagai penyebab terbesar kasus pneumonia. Pengobatan utama infeksi akibat bakteri ialah dengan antibiotik. Antibiotik merupakan obat yang paling banyak digunakan di pelayanan kesehatan (Rosdiana, Anggraini, Balmas, Effendi, \& Bet, 2018).

Tingginya penggunaan antibiotik untuk penyakit infeksi meningkatkan risiko penggunaan antibiotik secara tidak tepat yang dapat mengakibatkan tujuan terapi tidak tercapai. Berbagai studi menemukan bahwa sekitar 40-62\% antibiotik digunakan secara tidak tepat antara lain untuk penyakit-penyakit yang sebenarnya tidak memerlukan antibiotik. Penggunaan antibiotik yang tidak tepat dapat meningkatkan risiko resistensi yang berujung pada morbiditas bahkan mortalitas. Resistensi menyebabkan dampak terhadap peningkatan jumlah kematian dan beban ekonomi, karena perpanjangan lama rawat inap, penggunaan antibiotik yang lebih mahal dan lebih lama. Kematian akibat resistensi diperkirakan mencapai sekitar 700.000 jiwa (Kementerian Kesehatan RI, 2018). Pengetahuan tentang bakteri lokal penyebab infeksi dan tingkat sensitivitasnya terhadap antibiotik adalah faktor yang sangat penting dalam penentu keberhasilan terapi empiris (Grief \& Loza, 2018).

Berdasarkan penelitian di rumah sakit pemerintah daerah Madiun Jawa Timur diketahui bahwa Ceftriaxon adalah antibiotik yang dominan digunakan pada pasien pneumonia. Akan tetapi pada pneumonia yang disebabkan oleh Pseudomonas aeruginosa menunjukan telah resisten terhadap Ceftriaxon, sedangkan bakteri lain seperti Klabsiella pneumonia masih menunjukan sensitivitas sebesar 33,33\% (Farida, Puspita, \& Yusvida, 2019). Studi di rumah sakit rujukan daerah Surakarta menyebutkan bahwa Ceftriaxon juga merupakan antibiotik empirik yang paling banyak di resepkan pada pasien pneumonia dewasa (Farida, Trisna, \& Nur, 2017). Studi lain di rumah sakit di Indonesia melaporkan bahwa Pseudomonas aeruginosa telah resisten sebesar 60,9\% terhadap ceftriaxone sedangkan Klabsiella pneumonia resisten sebesar 75,7 \%(Radji, Fauziah, \& Aribinuko, 2011). Studi di Korea (2018) menyebutkan bahwa tingkat resistensi Streptococcus pneumonia terhadap Ceftriaxon masih rendah $(<10 \%)$. Sedangkan antibiotik dengan tingkat resistensi yang tinggi adalah golongan makrolida yaitu eritromisin 
dan azitromisin. Hal ini menunjukan bahwa tingkat sensitivitas bakteri dapat berbeda pada wilayah dan waktu pemeriksaan yang berbeda .

Sebuah studi menyebutkan bahwa perbedaan usia tidak menunjukan perbedaan bakteri penyebab tetapi berpengaruh terhadap outcome klinis, sedangkan adanya komorbid menunjukan pengaruh terhadap risiko kematian (Cillóniz et al, 2013). Hal ini menunjukan bahwa penting untuk mengetahui profil pasien agar dapat menjadi pertimbangan dalam menyusun panduan terapi. Selain itu adanya diagnosa penyakit komorbid akan menambah jumlah obat yang diberikan untuk terapi bagi pasien. Potensi interaksi obat meningkat dengan semakin banyaknya obat yang digunakan (Parulian, Listyanti, Hati, \& Sunnah, 2019). Pemberian antibiotik secara bersamaan dengan antibiotik lain, obat lain atau makanan dapat menimbulkan interaksi obat sehingga memiliki efek yang tidak diharapkan. Efek dari interaksi yang dapat terjadi cukup beragam mulai dari yang ringan seperti gangguan absorbsi obat hingga meningkatkan efek toksik obat lainnya (Baratawijaya, 2001)

Berdasarkan uraian tersebut, menunjukan bahwa studi tentang profil pasien, dan evaluasi penggunaan antibiotik secara berkala penting untuk dilakukan. Belum banyak studi di Indonesia yang membahas tentang kesesuaian pemberian antibiotik dengan hasil kultur. Selain itu. biasanya studi potensi interaksi obat dilakukan terpisah dengan evaluasi kesesuaian antibiotik. Penelitian ini bertujuan untuk mengetahui karakteristik pasien dan kesesuaian penggunaan antibiotik serta potensi interaksi obat yang dapat terjadi pada peresepan obatnya. Penelitian dilakukan pada subjek pasien dengan diagnosis Community-Acquired Pneumonia (CAP) yang dirawat inap pada periode 2018.

\section{Metode}

Penelitian ini dilakukan setelah mendapatkan ijin dari pihak rumah sakit dan komite etik dengan nomor 442/IV/HREC/2018. Penelitian yang dilakukan merupakan penelitian observasional untuk mengetahui gambaran penggunaan antibiotik pasien pneumonia. Populasi penelitian adalah pasien dewasa dengan diagnosis utama Community-Acquaired Pneumonia (CAP) yang dirawat inap pada periode Januari sampai Desember 2018. Sampel dalam penelitian ini diambil menggunakan teknik total sampling. Kriteria dalam pengambilan sampel adalah pasien berusia $\geq 18$ tahun, dengan diagnosa masuk pneumonia atau suspect pneumonia, dengan atau tanpa penyakit penyerta, serta yang mendapatkan terapi antibiotik. Pasien di exclude jika ada infeksi lain. Data diperoleh dari catatan rekam medis pasien secara retrospektif.

Rekam medis pasien digunakan untuk memperoleh data terkait usia, jenis kelamin, diagnosis penyakit utama \& penyakit penyerta, lama perawatan, hasil kultur (jika ada), nama antibiotik, dan penggunaan obat selain antibiotik. Data penggunaan antibiotik pada pasien 
pneumonia dianalisis secara deskriptif dengan pengambilan data dari catatan rekam medis. Data profil pasien dianalisis dengan menghitung persentase jenis kelamin, usia, lama perawatan, derajat keparahan dan penyakit komorbid. Derajat keparahan dihitung sendiri oleh peneliti dengan menggunakan metode skoring CURB-65 berdasarkan adanya gangguan kesadaran; kadar ureum $>20 \mathrm{mg} / \mathrm{dL}$; respiratory rate $>30 \mathrm{x} /$ menit, systolic blood pressure $\leq 90 \mathrm{mmHg}$ atau diastolicnya $\leq 60 \mathrm{mmHg}$ dan usia $>65$ tahun). Jika kondisi tersebut terpenuhi maka setiap kriteria bernilai satu sehingga rentang total skor adalah 0-5. Skor 0-1 masuk kategori risiko ringan, skor 2 kategori risiko sedang, dan skor $\geq 3$ berat (Andriyani, Keliat, \& Abidin, 2016). Untuk penggunaan antibiotik dilihat kesesuaian pemilihan antibiotik empirik dibandingkan data hasil kultur spesimen sputum pasien. Kemudian dilakukan penelusuran potensi interaksi obat dengan medscape drug interaction checker untuk melihat potensi adanya interaksi obat dilanjutkan penelusuran di buku Stockley Drug Interaction untuk melihat signifikansi, fase dan mekanisme terjadinya interaksi obat. Kombinasi obat yang berpotensi menimbulkan interaksi dihitung persentasenya dibandingkan dengan total peresepan.

\section{Hasil dan Pembahasan}

\subsection{Profil Pasien}

Karakteristik pasien pneumonia berdasarkan tabel 1 menunjukan bahwa pasien laki-laki lebih banyak dibandingkan dengan pasien perempuan (54,5\%). Menurut Henig \& Kaye (2017) jenis kelamin laki-laki dan kebiasaan merokok merupakan faktor risiko terjadinya CAP pada orang dewasa. Pasien usia lanjut menjadi subyek paling banyak $(43,6 \%)$ karena pada usia tersebut merupakan usia yang rentan terhadap infeksi pneumonia. Hal ini mungkin disebabkan oleh faktor-faktor seperti gangguan pembersihan saluran napas, pembersihan mukosiliar yang tidak efektif karena lemahnya otot-otot pernapasan, hilangnya elastisitas paru-paru, dan turunnya daya tahan tubuh (Nagesh, Rafiudeen, \& Rashmi, 2018).

Lama perawatan merupakan salah satu faktor yang dapat digunakan untuk mengukur tingkat efektivitas penggunaan obat. Berdasarkan tabel diketahui pasien paling banyak dirawat selama 1-7 hari (81,8\%). Terapi antibiotik pada pneumonia dapat diberikan 3-7 hari sehingga sebagian besar pasien sudah diperbolehkan pulang setelah dirawat 7 hari. Jika kondisinya belum membaik dapat dilanjutkan sampai 14 hari (Faizah \& Putra, 2019). Klasifikasi derajat keparahan penyakit bertujuan untuk memperoleh gambaran keparahan penyakit pasien dan untuk mengetahui rekomendasi tempat perawatan pasien. Derajat keparahan penyakit juga merupakan salah satu faktor yang mempengaruhi lama perawatan pasien. Metode yang digunakan adalah metode penilaian CURB-65 yang memiliki kelebihan yaitu penggunaannya yang sederhana, mudah, dan efisien dalam menilai karena hanya menggunakan 5 variabel 
penilaian (Sari, Almasdy, \& Fatimah, 2018; Shah et al, 2010). Pada penelitian ini pasien paling banyak mengalami derajat keparahan "Ringan" (45,5\%) yang didukung dengan hasil frekuensi lama perawatan pasien terbanyak pada rentang terendah yaitu 1-7 hari. Pada CURB-65, rekomendasi perawatan untuk tingkat "Ringan" adalah rawat jalan. Namun pada penelitian ini pasien dengan tingkat "Ringan" mendapatkan perawatan di rawat inap. Hal tersebut didukung dengan penelitian yang menemukan adanya mortalitas pada tingkat keparahan "Ringan" sehingga perawatan di rumah sakit diperlukan agar dapat mengurangi angka mortalitas pneumonia (Madhu et al, 2017).

Tabel 1. Profil karakteristik pasien pneumonia rawat inap di Rumah Sakit Akademik wilayah Sukoharjo dengan subyek penelitian $(\mathrm{N}=110)$. Keterangan asterisk $(*)$ yaitu $\mathrm{N}$ dibagi 110 dikali $100 \%$.

\begin{tabular}{|c|c|c|}
\hline Karakteristik & Frekuensi (N) & Persentase* \\
\hline \multicolumn{3}{|l|}{ Jenis kelamin } \\
\hline Laki-laki & 60 & $54,5 \%$ \\
\hline Perempuan & 50 & $45,5 \%$ \\
\hline \multicolumn{3}{|l|}{ Usia (tahun) } \\
\hline $18-25$ & 5 & $4,5 \%$ \\
\hline $26-35$ & 6 & $5,5 \%$ \\
\hline $36-45$ & 9 & $8,2 \%$ \\
\hline $46-55$ & 13 & $11,8 \%$ \\
\hline $56-65$ & 29 & $26,4 \%$ \\
\hline$>65$ & 48 & $43,6 \%$ \\
\hline \multicolumn{3}{|l|}{ Lama perawatan (hari) } \\
\hline $1-7$ & 90 & $81,8 \%$ \\
\hline $8-14$ & 18 & $16,4 \%$ \\
\hline $15-21$ & 1 & $0,9 \%$ \\
\hline$>21$ & 1 & $0,9 \%$ \\
\hline \multicolumn{3}{|l|}{ Derajat keparahan (CURB-65) } \\
\hline Ringan $($ Skor $<2)$ & 50 & $45,5 \%$ \\
\hline Sedang (Skor 2) & 27 & $24,5 \%$ \\
\hline Berat $($ Skor >2) & 33 & $30,0 \%$ \\
\hline \multicolumn{3}{|l|}{ Penyakit Komorbid } \\
\hline Penyakit Kardiovaskuler & 56 & $50,9 \%$ \\
\hline DM Tipe 2 & 25 & $22,7 \%$ \\
\hline $\mathrm{TB}$ & 23 & $20,9 \%$ \\
\hline Gangguan Ginjal & 14 & $12,7 \%$ \\
\hline PPOK & 13 & $11,8 \%$ \\
\hline Anemia & 9 & $8,2 \%$ \\
\hline Asma & 8 & $7,3 \%$ \\
\hline Demam Thypoid & 6 & $5,5 \%$ \\
\hline Gangguan Hati & 2 & $1,8 \%$ \\
\hline Serebrovaskuler & 1 & $0,9 \%$ \\
\hline
\end{tabular}


Pasien paling banyak menderita penyakit komorbid penyakit kardiovaskuler $(50,9 \%)$ seperti gagal jantung. Dalam penelitian Corrales-Medina et al, (2011) menyoroti hampir setengah dari pasien CAP menderita penyakit kardiovaskuler kronis dan CAP sangat erat hubungannya dengan komplikasi kejadian kardiovaskuler. Penelitian lain Ferreira et al (2019) menemukan bahwa pasien dengan penyakit komorbid diabetes mellitus tipe 2 (22,7\%) memiliki tingkat rawat inap tertinggi dan peningkatan risiko morbiditas serta mortalitas. Pasien penyakit TB (20,9\%) memiliki risiko koinfeksi dengan bakteri lainnya sehingga lebih rentan terhadap infeksi pneumonia dan penyaki TB dapat memperburuk prognosis mereka (Kan et al, 2019)

\subsection{Profil Penggunaan Antibiotik Empirik}

Pada penelitian ini antibiotik dibedakan menjadi dua kelompok yaitu pemberian antibiotik tunggal dan kombinasi. Profil penggunaan antibiotik dapat dilihat pada tabel 2 . Secara keseluruhan, pasien paling banyak diberikan terapi tunggal levofloxacin $(38,2 \%)$. Menurut Loscalzo (2016), levofloxacin merupakan terapi empiris pneumonia rawat inap untuk CAP. Levofloxacin merupakan antibiotik respiratory floroquinolon yang sangat direkomendasikan dengan level evidence yang tinggi (Lee et al, 2018). Terapi antibiotik bertujuan untuk mengeradikasi patogen penyebab infeksi. Pemberian terapi antibiotik empiris sedini mungkin setelah CAP terkonfirmasi sangat penting dalam mengurangi angka mortalitas (Metlay et al, 2019).

Tabel 2. Pola penggunaan antibiotik pemberian tunggal dan kombinasi pada pasien Community-Acquired Pneumonia $(\mathrm{N}=110)$ rawat inap di Rumah Sakit Akademik wilayah Sukoharjo. Keterangan asterisk (*) yaitu N dibagi 110 dikali $100 \%$.

\begin{tabular}{llc}
\hline \multicolumn{1}{c}{ Antibiotik } & Frekuensi (N) & Persentase* \\
\hline Tunggal & 42 & \\
Levofloxacin & 20 & $38,2 \%$ \\
Ceftriaxone & 12 & $18,2 \%$ \\
Ceftazidime & 4 & $10,9 \%$ \\
Cefotaxime & 2 & $3,6 \%$ \\
Azitromicin & 1 & $1,8 \%$ \\
Ampicilin & 1 & $0,9 \%$ \\
Cefopherazone & & $0,9 \%$ \\
\hline Kombinasi & 9 & \\
Ceftriaxone + Azitromicin & 6 & $8,2 \%$ \\
Ceftazidime + Levofloxacin & 6 & $5,5 \%$ \\
Ceftriaxone + Levofloxacin & 2 & $5,5 \%$ \\
Cefoperazone + Levofloxacin & 2 & $1,8 \%$ \\
Ceftazidim + Azitromicin & 1 & $1,8 \%$ \\
Cefoperazone + Gentamicin & 1 & $0,9 \%$ \\
Ceftazidime + Co amoxiclav & $0,9 \%$ \\
Ceftriaxone + Azitromicin + Ceftazidime & 1 & $0,9 \%$ \\
\hline
\end{tabular}


Pemberian antibiotik kombinasi dilakukan untuk infeksi yang berat (Lee et al, 2018). Pada penggunaan antibiotik kombinasi yang paling banyak digunakan yaitu kombinasi ceftriaxone dan azitromicin (8,2\%). Sesuai dengan rekomendasi dari beberapa literatur, diketahui bahwa terapi pasien rawat inap non ICU dewasa dapat menggunakan antibiotik beta laktam seperti seftriakson dikombinasikan dengan makrolida seperti azitromicin (Ruhe \& Mildvan, 2013; Watkins \& Lemonovich, 2011). Kombinasi ceftriaxone dan azitromicin menjadi salah satu pilihan terapi empiris lini pertama yang direkomendasikan oleh IDSA. Kombinasi keduanya sama efektifnya dengan pemberian tunggal levofloxacin (Izadi et al, 2018). Ceftriaxone memiliki efek bakterisidal dengan menghambat sintesis mukopeptida dinding sel bakteri (Rawls, 2014). Azitromicin aktif terhadap berbagai mikroorganisme, termasuk kokus gram-positif, bakteri anaerob, dan patogen atipikal (Yoshioka et al, 2016).

\subsection{Profil Bakteri Penyebab dan Antibiotik Empirik yang diresepkan}

Berdasarkan data hasil pemeriksaan laboratorium mikrobiologi, tidak semua subyek memiliki data hasil kultur sputum. Dari total 110 subyek penelitian, hanya terdapat 30 hasil kultur sputum pasien (table 3). Antibiotik empirik yang diresepkan pada pasien dicocokan kesesuaiannya dengan hasil kultur.

Kesesuaian antibiotik empirik yang diresepkan dengan hasil kultur sputum dapat dilihat pada tabel 3. Pada penelitian ini diketahui bahwa tidak semua antibiotik yang diresepkan adalah antibiotik yang masih sensitive berdasarkan hasil kultur. Hal ini terjadi karena hasil kultur membutuhkan waktu 3-5 hari sehingga pada beberapa pasien tidak dilakukan penyesuaian antibiotik karena respon klinik sudah membaik atau pasien sudah keluar rumah sakit atau pulang paksa.

Evaluasi penggunaan antibiotik yang digunakan adalah dengan melihat kesesuaian antara pemberian antibiotik dengan hasil kultur sputum (tabel 3). Sebanyak 80 pasien tidak dapat dilihat evaluasi kesesuaiannya karena tidak memiliki hasil kultur sputum. Dari data menunjukkan pasien paling banyak terinfeksi bakteri Streptococcus pneumonia. Bakteri tersebut merupakan bakteri patogen pneumonia yang paling umum dan banyak ditemukan di antara patogen lainnya (Harris et al, 2017). Studi di Amerika menyebutkan bahwa Streptococcus pneumonia merupakan salah satu diantara 5 terbanyak bakteri penyebab pneumonia (Metlay et al, 2019). Akan tetapi hasil ini berbeda dengan penelitian lain di Indonesia yang menyebutkan bahwa penyebab terbanyak pneumonia komunitas adalah 
Tabel 3. Kesesuaian penggunaan antibiotik empirik dengan hasil kultur pada pasien $(\mathrm{N}=30)$ rawat inap di Rumah Sakit Akademik wilayah Sukoharjo.. Keterangan asterisk (*) yaitu N dibagi 30 dikali $100 \%$.

\begin{tabular}{|c|c|c|c|c|}
\hline $\begin{array}{c}\text { Bakteri penyebab } \\
\text { (jumlah) }\end{array}$ & $\begin{array}{c}\text { Antibiotik yang } \\
\text { Sensitif }\end{array}$ & $\begin{array}{c}\text { Antibiotik yang } \\
\text { Diresepkan }\end{array}$ & Sesuai & $\begin{array}{l}\text { Belum } \\
\text { Sesuai }\end{array}$ \\
\hline $\begin{array}{c}\text { Acinetobacter } s p \\
(n=1)\end{array}$ & $\begin{array}{l}\text { Levofloxacin, } \\
\text { Ceftriaxone, } \\
\text { Cefotaxime }\end{array}$ & Ceftazidime & 0 & 1 \\
\hline $\begin{array}{c}\text { Citrobacter } s p \\
(n=2)\end{array}$ & $\begin{array}{l}\text { Co amoxiclav, } \\
\text { Ampicillin, } \\
\text { Levofloxacin }\end{array}$ & $\begin{array}{c}\text { Cefoperazone, } \\
\text { Ceftriaxone, Levofloxacin }\end{array}$ & 0 & 2 \\
\hline $\begin{array}{c}\text { Enterococcus sp } \\
(n=1)\end{array}$ & $\begin{array}{l}\text { Ampicilin, } \\
\text { Ceftriaxone }\end{array}$ & Ceftazidime & 0 & 1 \\
\hline $\begin{array}{l}\text { Eschericia coli } \\
(n=2)\end{array}$ & Co amoxiclav & Ceftriaxone, Levofloxacin & 0 & 2 \\
\hline $\begin{array}{c}\text { Klebsiella } \\
\text { pneumonia }(n=2)\end{array}$ & $\begin{array}{l}\text { Levofloxacin, } \\
\text { Co amoxiclav, } \\
\text { Ceftriaxone, } \\
\text { Cefotaxime }\end{array}$ & Cefotaxime, Levofloxacin & 2 & \\
\hline $\begin{array}{c}\text { Pseudomonas } \\
\text { aeruginosa }(n=4)\end{array}$ & $\begin{array}{l}\text { Levofloxacin, } \\
\text { Co amoxiclav, } \\
\text { Ampicillin }\end{array}$ & $\begin{array}{c}\text { Cefopherazone, } \\
\text { Ceftazidime, Co } \\
\text { amoxiclav, Levofloxacin }\end{array}$ & 1 & 3 \\
\hline $\begin{array}{l}\text { Staphylococcus } \\
\text { epidermidis }(n=1)\end{array}$ & $\begin{array}{l}\text { (semua } \\
\text { antibiotik } \\
\text { resisten) }\end{array}$ & Levofloxacin & 0 & 1 \\
\hline $\begin{array}{c}\text { Streptococcus } \\
\text { pneumonia }(n=9)\end{array}$ & $\begin{array}{l}\text { Ampicillin, } \\
\text { Levofloxacin, } \\
\text { Ceftriaxone }\end{array}$ & $\begin{array}{l}\text { Ampicillin, Ceftazidime, } \\
\text { Cefoperazone, } \\
\text { Gentamicin, Levofloxacin }\end{array}$ & 6 & 3 \\
\hline $\begin{array}{l}\text { Streptococcus } \\
\text { pyogene }(n=1)\end{array}$ & $\begin{array}{l}\text { Levofloxacin, } \\
\text { Ampicillin, } \\
\text { Ceftriaxone }\end{array}$ & Levofloxacin & 1 & 0 \\
\hline $\begin{array}{l}\text { Streptococcus } \\
\text { viridian }(n=4)\end{array}$ & $\begin{array}{l}\text { Levofloxacin, } \\
\text { Ampicillin, } \\
\text { Ceftriaxone }\end{array}$ & Levofloxacin & 4 & 0 \\
\hline $\begin{array}{c}\text { Streptococcus } \\
\text { pneumoniae dan } \\
\text { Enterobacter } \\
\text { aerogenes }(n=1)\end{array}$ & $\begin{array}{l}\text { Levofloxacin, } \\
\text { Ceftriaxone, } \\
\text { Cefotaxime }\end{array}$ & Ceftriaxone & 1 & 0 \\
\hline $\begin{array}{c}\text { Streptococcus } \\
\text { pneumoniae dan } \\
\text { Klebsiella } \\
\text { pneumonia }(n=2)\end{array}$ & $\begin{array}{l}\text { Ampicillin, } \\
\text { Levofloxacin, } \\
\text { Co amoxiclav, } \\
\text { Ceftriaxone, } \\
\text { Cefotaxime }\end{array}$ & Ceftriaxone, Levofloxacin & 2 & 0 \\
\hline & Total & & 17 & 13 \\
\hline & Persentase* & & $56,67 \%$ & $43,33 \%$ \\
\hline
\end{tabular}


Klabsiella pneumonia (Faisal et.al., 2014). Bakteri tersebut dilaporkan resisten terhadap antibiotik $\beta$ lactam melalui produksi extended spectrum betalactamase (ESBL) (Lin et al, 2016). Studi di Indonesia khususnya kota Medan melaporkan bahwa K.pneumonia masih memiliki sensitivitas yang baik terhadap golongan aminoglikosida dan carbapenem, sensitivitas sedang terhadap beberapa antibiotik seperti levofloxacin, ceftazidim, cotrimoxazole dan kurang sensitif terhadap amoxicillin dan ampicillin (Patilaya, Husori, \& Marhafanny, 2019).

\subsection{Potensi Interaksi Antibiotik dengan Obat lain dalam Peresepan Obat Pasien CAP}

Penggunaan antibiotik bersama dengan obat lain berpotensi untuk saling berinteraksi dan memberikan efek yang beragam dengan tingkat signifikansi minor hingga mayor (Farida \& Soleqah, 2016). Dari 37 item potensi terjadinya interaksi dapat dilihat bahwa potensi interaksi obat yang paling banyak terjadi pada fase farmakodinamik yaitu $23,6 \%$ dan pada signifikansi moderate sebanyak 20,9\% berdasarkan literatur. Literatur yang digunakan adalah Medscape Drug Interaction Checker, dan Stockley's Drug Interaction.

Analisis potensi interaksi obat dapat dilihat pada tabel 4. Potensi interaksi obat yang paling banyak pada signifikansi major yaitu antara levofloxacin- methylprednisolon $(26,4 \%)$. Efek samping yang dihasilkan keduanya adalah artropati dan tendinitis. Levofloxacin dapat menghasilkan perubahan reseptor kondrosit integrin di permukaan melalui mekanisme induksi stress oksidatif, inhibisi sintesis DNA, disfungsi mitokondrial pada kondrosit dan pembentukan ion magensium-kelat (Raini, 2016). Akibat mekanisme tersebut mempengaruhi bagian muskoloskeletal yaitu menyebabkan tendinitis. Terapi methylprednisolon sebagai kortikosteroid memiliki indikasi tendinitis sehingga keduanya akan saling menurunkan khasiat dan menjadikan levofloxacin tidak mencapai batas minimal terapeutik.

Potensi interaksi obat yang paling banyak pada signifikansi moderate yaitu levofloxacinmetformin, levofloxacin-ondansetron, dan levofloxacin-sucralfat dengan persentase masingmasing 9,1\%. Antibiotik fluorokuinolon seperti levofloxacin dapat mengganggu efek terapi metformin. Penggunaan levofloxacin menyebabkan gangguan homeostasis glukosa yang kemungkinan berasal dari efek pada saluran beta pankreas yang mengatur sekresi insulin. Efek selanjutnya yang dapat terjadi adalah hiperglikemik atau hipoglikemik berat. Pada umumnya, hiperglikemik secara signifikan menjadi faktor risiko pneumonia, tetapi hipoglikemik berisiko menyebabkan morbiditas dan mortalitas yang lebih besar (Ferreira et al, 2019). 
Tabel 4. Potensi interaksi antibiotik dengan obat lain pada pasien Community-Acquired Pneumonia $(\mathrm{N}=110)$ rawat inap di Rumah Sakit Akademik wilayah Sukoharjo. Keterangan asterisk (*) yaitu N dibagi 110 dikali $100 \%$.

\begin{tabular}{|c|c|c|c|c|c|}
\hline Antibiotik & Obat Lain & $\begin{array}{c}\text { Fase Interaksi } \\
\text { Obat }\end{array}$ & Signifikansi & $\begin{array}{c}\text { Jumlah } \\
\text { Peresepan } \\
\text { (N) }\end{array}$ & Persentase* \\
\hline \multirow[t]{6}{*}{ Azithromycin } & Albuterol & Farmakodinamik & Moderate & 2 & $1,8 \%$ \\
\hline & Cetirizine & Farmakodinamik & Minor & 2 & $1,8 \%$ \\
\hline & Fluconazole & Farmakodinamik & Moderate & 2 & $1,8 \%$ \\
\hline & Ondansetron & Farmakodinamik & Moderate & 4 & $3,6 \%$ \\
\hline & Vitamin B1 & Absorbsi & Moderate & 2 & $1,8 \%$ \\
\hline & Vitamin B6 & Absorbsi & Moderate & 2 & $1,8 \%$ \\
\hline Cefopherazone & Furosemide & Ekskresi & Moderate & 2 & $1,8 \%$ \\
\hline \multirow[t]{3}{*}{ Ceftazidime } & Aspirin & Ekskresi & Minor & 2 & $1,8 \%$ \\
\hline & Furosemide & Farmakodinamik & Moderate & 3 & $2,7 \%$ \\
\hline & Warfarin & Farmakodinamik & Moderate & 1 & $0,9 \%$ \\
\hline \multirow[t]{2}{*}{ Ceftriaxone } & Furosemide & Farmakodinamik & Moderate & 9 & $8,2 \%$ \\
\hline & Natrium diclofenac & Ekskresi & Minor & 1 & $0,9 \%$ \\
\hline \multirow[t]{2}{*}{ Gentamicin } & Aspirin & Ekskresi & Minor & 1 & $0,9 \%$ \\
\hline & Bisoprolol & Farmakodinamik & Moderate & 1 & $0,9 \%$ \\
\hline \multirow[t]{24}{*}{ Levofloxacin } & Acarbose & Farmakodinamik & Moderate & 2 & $1,8 \%$ \\
\hline & Alprazolam & Metabolisme & Minor & 4 & $3,6 \%$ \\
\hline & $\begin{array}{l}\text { Aluminum } \\
\text { hydroxide }\end{array}$ & Absorbsi & Moderate & 2 & $1,8 \%$ \\
\hline & Aspirin & Farmakodinamik & Moderate & 9 & $8,2 \%$ \\
\hline & Dexamethasone & Farmakodinamik & Major & 5 & $4,5 \%$ \\
\hline & Hydrocortisone & Farmakodinamik & Major & 2 & $1,8 \%$ \\
\hline & Insulin aspart & Farmakodinamik & Major & 3 & $2,7 \%$ \\
\hline & Insulin detemir & Farmakodinamik & Major & 5 & $4,5 \%$ \\
\hline & Insulin glargine & Farmakodinamik & Major & 6 & $5,5 \%$ \\
\hline & Ketorolac & Farmakodinamik & Moderate & 6 & $5,5 \%$ \\
\hline & Lactulose & Farmakodinamik & Moderate & 3 & $2,7 \%$ \\
\hline & $\begin{array}{l}\text { Magnesium } \\
\text { hydroxide }\end{array}$ & Absorbsi & Moderate & 2 & $1,8 \%$ \\
\hline & Meloxicam & Farmakodinamik & Moderate & 1 & $0,9 \%$ \\
\hline & Metformin & Farmakodinamik & Moderate & 10 & $9,1 \%$ \\
\hline & Methylprednisolone & Farmakodinamik & Major & 29 & $26,4 \%$ \\
\hline & Metronidazole & Farmakodinamik & Minor & 2 & $1,8 \%$ \\
\hline & Ondansetron & Farmakodinamik & Moderate & 10 & $9,1 \%$ \\
\hline & Phenytoin & Farmakodinamik & Moderate & 1 & $0,9 \%$ \\
\hline & Sucralfate & Absorbsi & Moderate & 10 & $9,1 \%$ \\
\hline & Triamcinolone & Farmakodinamik & Major & 1 & $0,9 \%$ \\
\hline & Terbutaline & Farmakodinamik & Moderate & 1 & $0,9 \%$ \\
\hline & Vitamin B1 & Absorbsi & Minor & 2 & $1,8 \%$ \\
\hline & Vitamin B6 & Absorbsi & Minor & 3 & $2,7 \%$ \\
\hline & Warfarin & Farmakodinamik & Moderate & 1 & $0,9 \%$ \\
\hline
\end{tabular}


Potensi interaksi yang terjadi pada levofloxacin-ondansetron berada pada fase farmakodinamik. Levofloxacin menginduksi hambatan HERG/Ikr, dan dapat menyebabkan perpanjangan interval QT (Raini, 2016). Perpanjangan interval QT dapat menghasilkan efek aditif dan peningkatan risiko aritmia ventrikel termasuk kematian mendadak. Namun, Sebagian besar potensi perpanjangan QT tidak dapat diprediksi. Potensi ini diperparah oleh faktor risiko seperti sindrom QT panjang bawaan, penyakit jantung, dan gangguan elektrolit (Cornett et al, 2017).

Potensi interaksi yang terjadi pada levofloxacin-sucralfat berada pada fase absorbsi obat. Sediaan oral yang mengandung magnesium, kalsium, atau aluminium, seperti sucralfat, dapat mengurangi penyerapan gastrointestinal fluorokuinolon. Penyerapan juga dapat dikurangi oleh sucralfat, yang mengandung aluminum, serta kation polivalen lainnya seperti Fe dan Zn. Mekanismenya adalah kelasi fluorokuinolon oleh kation-kation polivalen, membentuk suatu kompleks yang kurang terserap dari saluran pencernaan. Bioavailabilitas fluorokuinolon berkurang ketika diberikan sucralfat (Olajuyigbe, Adeoye-Isijola, Osopale, \& Coopoosamy, 2018).

Potensi interaksi obat yang paling banyak pada signifikasi minor yaitu levofloxacinalprazolam (3,6\%). Levofloxacin mempengaruhi kadar Alprazolam melalui mekanisme penghambatan enzim CYP. Hal ini dapat memperlambat biotransformasi alprazolam sehingga bioavailabilitas alprazolam dalam tubuh akan meningkat. Peningkatan bioavailabilitas alprazolam dapat meningkatkan dan memperpanjang durasi efeknya, sehingga risiko kematian meningkat (Farida \& Soleqah, 2016).

Kelemahan pada penelitian ini adalah terbatasnya data hasil kultur karena tidak semua pasien diambil spesimennya untuk kultur. Selain itu karena penelitian bersifat retrospektif maka makna klinis interaksi obat belum dapat dilihat.

\section{Kesimpulan}

Pasien CAP rawat inap Rumah Sakit UNS 2018 didominasi oleh pasien berjenis kelamin laki-laki $(54,5 \%)$, pasien berusia $>65$ tahun $(43,6 \%)$, pasien dengan lama perawatan 1-7 hari $(81,8 \%)$, pasien dengan derajat keparahan "Ringan" (45,5\%), dan penyakit komorbid kardiovaskuler (50,9\%). Terapi tunggal levofloxacin adalah antibiotik yang terbanyak diresepkan $(38,2 \%)$, yang berpotensi menimbulkan interaksi obat pada penggunaan bersama dengan methylprednisolon $(26,4 \%)$.

\section{Ucapan Terimakasih}

Terima kasih kepada Universitas Sebelas Maret atas dana Hibah Penelitian Fundamental PNBP tahun 2019. 


\section{Deklarasi Konflik Kepentingan}

Semua penulis menyatakan tidak ada konflik kepentingan terhadap naskah ini.

\section{Daftar Pustaka}

Andriyani, S., Keliat, E. N., dan Abidin, A. (2016). Hubungan Derajat Skor CURB-65 Saat Awal Masuk dan Nilai Antitrombin III pada Pasien Pneumonia Komunitas Correlation between CURB-65 and Antithrombin III Scores in Community Acquired Pneumonia at Early Admission in Hospital. Majalah Kedokteran Bandung, 48(2), 92-97.

Baratawijaya. (2001). Imunologi Dasar. Jakarta: fakultas Kedokteran Universitas Indonesia.

Cillóniz, C., Polverino, E., Ewig, S., Aliberti, S., Gabarrús, A., Menéndez, R., Mensa., J., Blasi, F., Torres, A. (2013). Impact of Age and Comorbidity on Cause and Outcome in Community-Acquired Pneumonia. CHEST, 144(3), 999-1007.

Cornett, E., Novitch, M. B., Kaye, A. D., Pann, C. A., Bangalore, H. S., Allred, G., Bral, M., Jhita, P.K., Kaye, A. M. (2017). Macrolide and fluoroquinolone mediated cardiac arrhythmias: clinical considerations and comprehensive review. Postgraduate Medicine, 129(7), pp. 715-724.

Corrales-Medina, V. F., Suh, K. N., Rose, G., Chirinos, J. A., Doucette, S., Cameron, D. W., \& Fergusson, D. A. (2011). Cardiac Complications in Patients with Community-Acquired Pneumonia: A Systematic Review and Meta-Analysis of Observational Studies. PLoS Medicine, 8(6).

Faisal, F., Burhan, E., Aniwidyaningsih, W., \& Kekalih, A. (2014). Penilaian Respons Pengobatan Empiris pada Pasien Rawat Inap dengan Pneumonia Komunitas Evaluation of Empirical Treatment Responsse in Hospitalized Patient Community Acquired Pneumonia. J Respir Indo, 34(2), 60-70.

Faizah, A. K., \& Putra, O. N. (2019). Evaluasi Kualitatif Terapi Antibiotik pada Pasien Pneumonia di Rumah Sakit Pendidikan Surabaya Indonesia. Jurnal Sains Farmasi \& Klinis, 6(2), 129.

Farida, Y., Puspita, K., \& Yusvida, Z. (2019). Empirical Antibiotiks Study on Pneumonia in Intensive Care Unit. Proceedings of the 1st Muhammadiyah International Conference on Health and Pharmaceutical Development (MICH-PhD 2018), (36), 48-53. Farida, Y., \& Soleqah, A. D. (2016). Identification Of Potentialantibiotiks - Drugs interaction On Pneumonia Prescription. JPSCR: Journal of Pharmaceutical Science and Clinical Research, 1(2), 90.

Farida, Y., Trisna, A., \& Nur, D. (2017). Study of Antibiotik Use on Pneumonia Patient in Surakarta Referral Hospital. Journal of Pharmaceutical Science and Clinical Research, . 02(1), 44-52.

Ferreira, L., Moniz, A. C., Carneiro, A. S., Miranda, A. S., Fangueiro, C., Fernandes, D., Silva, I., Palhinhas, I., Lemos. J., Antunes, J., Leal, M., Sampaio, N., Faria, S. (2019). The impact of glycemic variability on length of stay and mortality in diabetic patients admitted with community-acquired pneumonia or chronic obstructive pulmonary disease. Diabetes and Metabolic Syndrome: Clinical Research and Reviews, 13(1), 149-153.

Grief, S. N., \& Loza, J. K. (2018, September 1). Guidelines for the Evaluation and Treatment of Pneumonia. Primary Care - Clinics in Office Practice, Vol. 45, pp. 485-503.

Harris, A. M., Bramley, A. M., Jain, S., Arnold, S. R., Ampofo, K., Self, W. H., Williams, D.J., Anderson, E.J., Grijalva, C.G., McCullers, J.A., Pavia, A.T., Wunderink, R.G., Edwards, K.M., Winchell, J.M., Hicks, L. A. (2017). Influence of Antibiotiks on the Detection of Bacteria by Culture-Based and Culture-Independent Diagnostic Tests in Patients Hospitalized With Community-Acquired Pneumonia. Open Forum Infectious Disease, $4(1), 1-7$.

Henig, O., \& Kaye, K. S. (2017). Bacterial Pneumonia in Older Adults. Infectious Disease Clinics of North America, 31(4), pp. 689-713. 
Iliyasu, G., Mohammad, F. D., \& Habib, A. G. (2018). Community acquired pneumococcal pneumonia in northwestern Nigeria: Epidemiology, antimicrobial resistance and outcome. African Journal of Infectious Diseases, 12(1), 15-19.

Izadi, M., Dadsetan, B., Najafi, Z., Jafari, S., Mazaheri, E., Dadras, O., Hajar, H., SeyedAhmad, A., Voltarelli, F. (2018). Levofloxacin Versus Ceftriaxone and Azithromycin Combination in the Treatment of Community Acquired Pneumonia in Hospitalized Patients. Recent Patents on Anti-Infective Drug Discovery, 13(3), 228-239.

Kan, T., Komiya, K., Honjo, K., Uchida, S., Goto, A., Kawano, H., Takikawa, S., Yoshimatsu, T., Kadota, J. (2019). Impact of additional antibiotiks on in-hospital mortality in tuberculosis isolated general bacteria: A propensity score analysis. Journal of Infection and Chemotherapy, 25(9), 714-719.

Kementerian Kesehatan Republik Indonesia. (2018). Laporan Nasional Riset Kesehatan Dasar 2018 (Report of Indonesian Basic Health Survey 2018).

Lee, M. S., Oh, J. Y., Kang, C. I., Kim, E. S., Park, S., Rhee, C. K., Jung, J.Y., Jo, K.W., Heo, E.Y., Park, D.A. and Kiem, S. (2018). Guideline for Antibiotik Use in Adults with Community-acquired Pneumonia. Infection \& Chemotherapy, 50(2), 160-198.

Lin, W. P., Wang, J. T., Chang, S. C., Chang, F. Y., Fung, C. P., Chuang, Y. C., Chen, Y.S., Shiau, Y.R., Tan, M.C., Wang, H.Y., Lai, J.F., Huang, I.W. and Lauderdale, T. L. (2016). The Antimicrobial Susceptibility of Klebsiella pneumoniae from Community Settings in Taiwan, a Trend Analysis. Scientific Reports, 6.

Madhu, S., Augustine, S., Ravi Kumar, Y. S., Kauser M. M., K., Kumar, S. R. V., \& Jayaraju, B. S. (2017). Comparative study of CURB-65, Pneumonia Severity Index and IDSA/ATS scoring systems in community acquired pneumonia in an Indian tertiary care setting. International Journal of Advances in Medicine, 4(3), 693.

Metlay, J. P., Waterer, G. W., Long, A. C., Anzueto, A., Brozek, J., Crothers, K., Cooley, L.A., Dean, N.C., Fine, M.J., Flanders, S.A., Griffin, M.R., Metersky, M.L., Musher, D.M., Restrepo, M.I., Whitney, C. G. (2019). Diagnosis and treatment of adults with community-acquired pneumonia. American Journal of Respiratory and Critical Care Medicine, 200(7), E45-E67.

Nagesh, K. T. C., Rafiudeen, R., \& Rashmi, K. (2018). A study of clinical and etiological profile of community-acquired pneumonia with special reference to atypical pneumonia. Annals of Nigerian Medicine, 11(1), 11.

Olajuyigbe, O. O., Adeoye-Isijola, M. O., Osopale, B. A., \& Coopoosamy, R. M. (2018). In vitro effects of magnesium-aluminum hydroxide (maalox) on the antibacterial activity of ciprofloxacin against clinical bacterial isolates. Journal of Pure and Applied Microbiology, 12(2), 623-632.

Parulian, L., Listyanti, E., Hati, A. K., \& Sunnah, I. (2019). Analisis Hubungan Polifarmasi Dan Interaksi Obat Pada Pasien Rawat Jalan Yang Mendapat Obat Hipertensi Di Rsp. Dr. Ario Wirawan Periode Januari-Maret 2019. Indonesian Journal of Pharmacy and Natural Product, 02(2), 79-86.

Patilaya, P., Husori, D. I., \& Marhafanny, L. (2019). Susceptibility of klebsiella pneumoniae isolated from pus specimens of post-surgery patients in Medan, Indonesia to selected antibiotiks. Open Access Macedonian Journal of Medical Sciences, 7(22), 3861-3864.

Radji, M., Fauziah, S., \& Aribinuko, N. (2011). Antibiotik sensitivity pattern of bacterial pathogens in the intensive care unit of Fatmawati Hospital, Indonesia. Asian Pacific Journal of Tropical Biomedicine, 1(1), 39-42.

Raini, M. (2016). Antibiotik Golongan Fluorokuinolon: Manfaat dan Kerugian Fluoroquinolones Antibiotiks: Benefit and Side Effects. Media Litbangkes, 26(3), 163174.

Rawls, S. M. (2014). Antibiotiks, $\beta$-Lactam. In Encyclopedia of the Neurological Sciences (pp. 207-209). 
Rosdiana, D., Anggraini, D., Balmas, M., Effendi, D., \& Bet, A. (2018). Peningkatan Rasionalitas Penggunaan Antibiotik Pasca Implementasi Kebijakan Penggunaan Antimikroba di RSUD Arifin Achmad Pekanbaru. Jurnal Kedokteran Brawijaya, 30(1), 36.

Ruhe, J., \& Mildvan, D. (2013). Does Empirical Therapy with a Fluoroquinolone or the Combination of a $\beta$-Lactam Plus a Macrolide Result in Better Outcomes for Patients Admitted to the General Ward?- ClinicalKey. Infectious Disease Vlinivs of North America, 27(1), 115-132.

Sari, Y. O., Almasdy, D., \& Fatimah, A. (2018). Evaluasi Penggunaan Antibiotik Pada Pasien Ulkus Diabetikum di Instalasi Rawat Inap (IRNA) Penyakit Dalam RSUP Dr. M. Djamil Padang. JSFK (Jurnal Sains Farmasi \& Klinis), 5(2), 102-111.

Shah, B. A., Ahmed, W., Dhobi, G. N., Shah, N. N., Khursheed, S. Q., \& Haq, I. (2010). Validity of pneumonia severity index and CURB-65 severity scoring systems in community acquired pneumonia in an Indian setting. The Indian Journal of Chest Diseases \& Allied Sciences, 52(1), 9-17.

Watkins, R. R., \& Lemonovich, T. L. (2011). Diagnosis and Management of CommunityAcquired Pneumonia in Adults. American Family Physician, 83(11), 1299-1306.

Yoshioka, D., Kajiwara, C., Ishii, Y., Umeki, K., Hiramatsu, K., Kadota, J. I., \& Tateda, K. (2016). Efficacy of $\beta$-lactam-plus-macrolide combination therapy in a mouse model of lethal pneumococcal pneumonia. Antimicrobial Agents and Chemotherapy, 60(10), $6146-6154$.

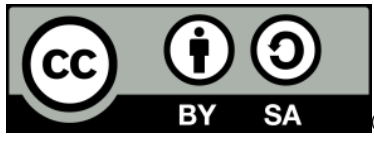

2020 by the authors. Submitted for possible open access publication under the terms and conditions of the Creative Commons Attribution-ShareAlike 4.0 International (CC BY-SA 4.0) license (https://creativecommons.org/licenses/by-sa/4.0/). 